\section{Estudo dos bloqueios de ramo em pacientes chagásicos crônicos assintomáticos. Contribuição do estudo eletrofisiológico}

\begin{abstract}
Este estudo foi elaborado com o objetivo de avaliar, prospectivamente, o potencial evolutivo, a longo prazo, dos transtornos da condução intraventricular em pacientes assintomáticos, portadores da doença de Chagas e comparálos com transtornos não chagásicos, verificando - aparecimento de bloqueios $\mathrm{AV}$, que necessitaram de implante de marcapasso e a mortalidade total e cardíaca. Foram critérios de inclusão: indivíduos assintomáticos, sem antecedentes de cardiopatia, de qualquer sexo, idade ou raça, eletrocardiograma de 12 derivações motrando ritmo sinusal, intervalo PR $\leq 0,20$ s e presença de bloqueio de ramo, e área cardíaca normal à radiografia do tórax. Foram estudados 84 indivíduos portadores de bloqueio de ramo direito ou esquerdo, sendo 55 com reações sorológicas positivas para a doença de Chagas (grupo $\mathrm{CH}$ ) e 29 não chagásicos (grupo $\mathrm{NCH}$ ). No grupo $\mathrm{CH}$, a idade variou entre 25 e 76 anos (média \pm desviopadrão - 45,75 $\pm 11,20$ ) e no grupo $\mathrm{NCH}$ entre 36 e 87 anos $(63 \pm 12,72)(p<0,001)$. Havia maior número de indivíduos com menos de 60 anos no grupo $\mathrm{CH}$ que no grupo $\mathrm{NCH}$ ( $\mathrm{p}<$ $0,001)$. No grupo $\mathrm{CH}$ havia $33(60 \%)$ homens e $22(40 \%)$ mulheres enquanto no grupo $\mathrm{NCH}$ havia 17 (58,62\%) homens e 12 (41,38\%) mulheres (NS). Todos foram submetidos a estudo eletrofisiológico invasivo, tendo sido avaliada a freqüência cardíaca basal, os intervalos $\mathrm{AH}$ e HV, o tempo máximo de recuperação do nódulo sinusal e o ponto de Wenckebach. $\mathrm{O}$ grupo $\mathrm{CH}$ tinha $54(98,18 \%)$ pacientes portadores de bloqueio completo do ramo direito (isolado ou associado a hemibloqueio anterior esquerdo e direito), enquanto que o $\mathrm{NCH}$ tinha 14 (48,27\%) com o mesmo tipo de bloqueio de ramo ( $p<0,001)$. O estudo eletrofisiológico não mostrou diferenças estatisticamente significantes entre as médias das freqüências cardíacas basais dos dois grupos, bem como entre as médias dos intervalos $\mathrm{AH}$, do tempo máximo de recuperação do nódulo sinusal e do ponto de Wenckebach. A
\end{abstract}

\section{Evaluation of the asymptomatic chronic chagasic individuals with bundle branch block. Role of the electrophysiologic studies}

This study was designed to evaluate prospectively the intraventricular conduction disturbances in asymptomatic patients with Chagas' disease (group $\mathrm{CH}$ ), and to compare to patients with primary sclerosis of the conducting system of the heart (Lev-Lenègre's disease group $\mathrm{NCH}$ ). The inclusion criteria were: asymptomatic individuals, of any sex, age or race, with no past history of cardiac disease, 12 lead ECG showing normal sinus rhythm, normal AV conduction and bundle branch block, and normal cardiac sillouette on chest X-ray. Eightyfour asymptomatic individuals with right or left bundle branch block were submitted to electrophysiological evaluation and long-term follow-up. Fifty-five had positive serologic blood tests for Chagas' disease and 29 had LevLenègre's disease. Group $\mathrm{CH}$ had mean-age of $45.75 \pm 11.20$ years (range from 25 to 76 ) and group $\mathrm{NCH} 63 \pm 12.72$ (range from 36 to 87 ) $(\mathrm{p}<0.001)$. Group $\mathrm{CH}$ had $33(60 \%)$ men and group NCH 17 (60.68\%) (NS). Group $\mathrm{CH}$ had $54(98.18 \%)$ with right bundle branch block isolated or associated with left anterior and posterior fascicular blocks - and group $\mathrm{NCH}$ had $14(48.27 \%)$ with right bundle branch block $(p<0.001)$. Sinus nodal function and atrioventricular nodal function, were not different in either group. However, mean HV interval was greater in group $\mathrm{NCH}$ than in the group $\mathrm{CH}(\mathrm{p}<0.01)$. The number of individuals with sinus nodal dysfunction and atrioventricular intranodal abnormalities was not different in either group, and prolonged HV interval was recorded in $49.27 \%$ in group $\mathrm{NCH}$ vs. $18.18 \%$ in group $\mathrm{CH}(\mathrm{p}<0.01)$. After a mean follow-up of $121 \pm 63.75$ months (range from 2 to 222 - median of 118) in group $\mathrm{CH}$ and $94.97 \pm 67.55$ months (range from 5 to 223 median of 74) in group $\mathrm{NCH}$ (NS), total mortality was $20(36.66 \%)$ patients in group $\mathrm{CH}$ and 9 $(31.03 \%)$ patients in group NCH (NS). Cardiac death was recorded in 17 (85\%) individuals in

Recebido para publicação em 31/10/97. 
média do intervalo $\mathrm{HV}$ mostrou-se maior no grupo $\mathrm{NCH}(p<0,001)$. A avaliação individualizada mostrou que no grupo $\mathrm{CH}$ havia proporcionalmente mais pacientes com disfunção do nódulo sinusal e do nódulo AV, porém, sem significância estatística. No grupo $\mathrm{NCH}$, havia maior número de indivíduos com alteração no sistema HisPurkinje $(p<0,01)$. Após seguimento médio de $121 \pm 63,75$ meses (entre 2 e 222 - mediana de 118) no grupo $\mathrm{CH}$ e $94,97 \pm 67,55$ (entre 5 e 223 - mediana de 74) no grupo NCH (NS), observou-se que a mortalidade total no grupo $\mathrm{CH}$ foi de $20(36,66 \%)$ pacientes e no grupo $\mathrm{NCH}$ foi de $9(31,03 \%)$ indivíduos (NS). Morte de causa cardíaca foi documentada em 17 (85\%) indivíduos no grupo $\mathrm{CH}$ e $3(33,33 \%)$ indivíduos no grupo $\mathrm{NCH}(\mathrm{p}<0,05)$. Morte súbita ocorreu em $10(50 \%)$ pessoas no grupo $\mathrm{CH}$, sem ter sido observada no grupo $\mathrm{NCH}(\mathrm{p}<0,01)$. A necessidade de implante de marcapasso foi observada em $13(23,66 \%)$ indivíduos no grupo $\mathrm{CH}$ e $4(13,79 \%)$ no grupo $\mathrm{NCH}$ (NS). O desenvolvimento de bloqueio $\mathrm{AV}$ e a necessidade de implante de marcapasso ocorreram em $6(10,90 \%)$ indivíduos do grupo $\mathrm{CH}$ e $4(13,79 \%)$ do grupo $\mathrm{NCH}$ (NS). No grupo $\mathrm{CH}, 7(12,72 \%)$ indivíduos receberam implante de marcapasso devido à disfunção do nódulo sinusal, sendo que no grupo NCH não houve este tipo de indicação. Não foi observada relação significante entre disfunção do nódulo sinusal e mortalidade, assim como alteracões do nódulo $\mathrm{AV}$ e do sistema His-Purkinje, isoladas ou simultaneamente. A evolução para formas sintomáticas de disfunção do nódulo sinusal correlacionou-se de forma significante com alterações da função sinusal detectadas no estudo eletrofisiológico, apenas no grupo $\mathrm{CH}(\mathrm{p}<0,05)$. Este estudo pode sugerir as seguintes conclusões: 1 . Os indivíduos chagásicos assintomáticos com distúrbios da condução intraventricular apresentaram maior mortalidade cardíaca súbita ou não súbita, que os indivíduos não chagásicos. 2. Os parâmetros eletrofisiológicos estudados não tiveram valor prognóstico quanto à mortalidade. 3 . A presença de tempo de recuperação do nódulo sinusal aumentado foi importante indicador de futura disfunção sintomática do nódulo sinusal. 4. O intervalo HV aumentado sugeriu evolução para formas avançadas de bloqueio $\mathrm{AV}$ e group $\mathrm{CH}$ and 3 (33.33\%) individuals in group $\mathrm{NCH}(p<0.05)$. Sudden death occurred in 10 $(50 \%)$ in group $\mathrm{CH}$ and it was not observed in group NCH $(\mathrm{p}<0.01)$. Pacemaker implantation was performed in $13(23.66 \%)$ patients of the group $\mathrm{CH}$ and in $4(13.79 \%)$ patients of the group NCH (NS). Development of AV block and treatment with permanent pacemaker implantation was observed in $6(10.90 \%)$ patients in the group $\mathrm{CH}$ and in $4(13.79 \%)$ patients of the group $\mathrm{NCH}$ (NS). In the group $\mathrm{CH}, 7$ (12.72\%) patients received pacemaker implantation due to sinus nodal dysfunction but this abnormality did not occur in the group $\mathrm{NCH}$. No relationship was noted between mortality and sinus nodal dysfunction, AV nodal abnormalities or dysfunction of the His-Purkinje system in either group. Development of symptomatic forms of sinus nodal dysfunction presented significant relationship with sinus nodal abnormalities detected in the electrophysiological studies, only in group $\mathrm{CH}$. It was concluded: 1. Asymptomatic chagasic individuals with intraventricular conduction disturbances showed higher cardiac mortality, sudden or nonsudden death in relation to the nonchagasic ones. 2 . The evaluated electrophysiologic parameters did not have prognostic values in relation to mortality. 3. Prolonged sinus nodal recovery time was an important predictor of development of symptomatic sinus nodal dysfunction. 4. Prolonged $\mathrm{HV}$ interval suggested progression to AV block and necessity of pacemaker implantation, only in the chagasic individuals.

\author{
João Pimenta \\ Tese apresentada ao IAMSPE - Hospital do Servidor \\ Público Estadual, São Paulo, SP para \\ obtenção do Título de Doutor. \\ São Paulo, SP, Brasil, 1997.
}

